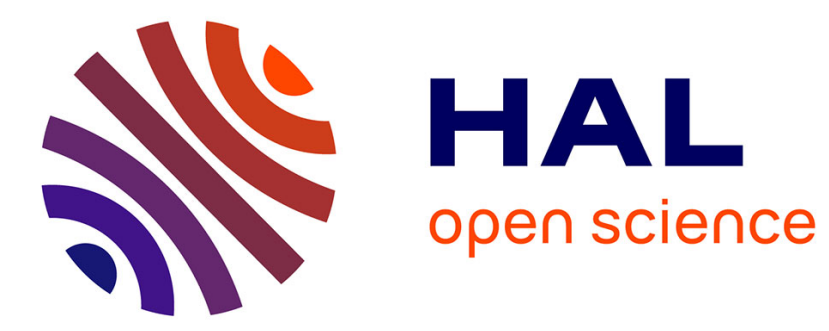

\title{
Reduced N supply limits the nitrate content of flue-cured tobacco
}

Castelli, Ceotto, Contillo

\section{To cite this version:}

Castelli, Ceotto, Contillo. Reduced N supply limits the nitrate content of flue-cured tobacco. Agronomy for Sustainable Development, 2011, 31 (2), pp.329-335. 10.1051/agro/2010033 . hal-00930462

\section{HAL Id: hal-00930462 \\ https://hal.science/hal-00930462}

Submitted on 1 Jan 2011

HAL is a multi-disciplinary open access archive for the deposit and dissemination of scientific research documents, whether they are published or not. The documents may come from teaching and research institutions in France or abroad, or from public or private research centers.
L'archive ouverte pluridisciplinaire HAL, est destinée au dépôt et à la diffusion de documents scientifiques de niveau recherche, publiés ou non, émanant des établissements d'enseignement et de recherche français ou étrangers, des laboratoires publics ou privés. 


\title{
Original article
}

\section{Reduced N supply limits the nitrate content of flue-cured tobacco}

\author{
Fabio CASTELli ${ }^{1}$, Enrico CEOTTO $^{2 *}$, Renato CONTILlO $^{3}$ \\ ${ }^{1}$ CRA-CAT, Unità di ricerca per le colture alternative al tabacco, via Canton 14, 37051 Bovolone (VR), Italy \\ ${ }^{2}$ CRA-CIN, Centro di ricerca per le colture industriali, via di Corticella 133, 40128 Bologna, Italy \\ ${ }^{3}$ CRA-CAT, Unità di ricerca per le colture alternative al tabacco, via Vitiello 108, 84018 Scafati (SA), Italy
}

(Accepted 10 June 2010) (Published online: 15 September 2010)

\begin{abstract}
Among tobacco components, nitrate is one of the most harmful for human health because during tobacco burning nitrate reacts with alkaloids to form tobacco-specific nitrosamines. Nitrosamines are carcinogenic compounds identified in tobacco products and smoke. Despite a general consensus on the relevance of nitrate on human health, nitrate is currently not considered in the routine analysis of flue-cured tobacco, unlike total alkaloids, reducing sugars, total nitrogen, pesticides and chemicals for sucker control residues. In implementing strategies for tobacco cultivation, it is critical to minimize the nitrate content of the harvested product. On the other hand, the agronomic practices devised to reduce nitrate content should not adversely impact either the yield or commercial characteristics of the product. We carried out a field experiment over three years at one site of the Veneto plane, Northern Italy. We studied the influence of nitrogen supply on productivity and relevant chemical characteristics of flue-cured tobacco. Treatments consisted of four rates of nitrogen supply and one unfertilized control. The rates of nitrogen applied were $0,15,30,45$ and $60 \mathrm{~kg} \mathrm{Nha}^{-1}$ in 1997, and 0, 20, 40, 60 and $80 \mathrm{~kg} \mathrm{Nha}^{-1}$ in both 1998 and 1999 . Our results show that annual fertilization rates within $40 \mathrm{~kg} \mathrm{~N} \mathrm{ha}^{-1}$ fulfilled the crops' requirements for productivity, with no adverse effects on product quality. Higher rates of nitrogen supply resulted in undesired increment in nitrate concentration and reduced sugar content in the cured product, without any gain in productivity. Moreover, we found no correlation between total nitrogen and nitrate concentrations of tobacco cured leaves. Since our data provide evidence that nitrogen content is not a reliable estimator of the harmful nitrate content, we suggest that nitrate should be taken under control in the routine analysis for assessing flue-cured tobacco quality.
\end{abstract}

product quality / harmful compounds / productivity / nitrate / cancer / nitrosamine / tobacco

\section{INTRODUCTION}

Nitrogen is often the most important growth-limiting factor for all crop plants. Thus, nitrogen fertilizers are commonly applied to increase crop yield and quality. Most of the nitrogen absorbed by the plants is incorporated into protein, while a fraction remains in the form of non-protein nitrogen, mainly amino acids and nitrate (Blumenthal et al., 2001).

When input of nitrogen exceeds the plant's needs, nitrate tends to accumulate in the leaves (Cardenas-Navarro et al., 1999). High nitrate accumulation in plants, notably in fresh vegetables, is a general concern for its human health implications (Anjana and Iqbal, 2006). Unlike food and feed crops, tobacco typically produces leaves used for smoking, and this implies specific concern for human health. In both plants and animals, nitrate can be reduced to nitrite, by which nitrosation reactions produce carcinogenic $\mathrm{N}$-nitroso compounds (Wolfe and Patz, 2002). The so-called tobacco-specific $\mathrm{N}$-nitrosamines are recognized to have special significance

* Corresponding author: enrico.ceotto@entecra.it among the class of carcinogenic compounds identified in tobacco and in the smoke of tobacco (Hoffmann and Hoffmann, 1997). Green and freshly harvested tobacco leaves usually contain nitrate but are virtually free of tobacco-specific Nnitrosamines. It is during the post-harvest processing, and also during tobacco combustion, that nitrate is reduced to nitrite which then reacts with tobacco alkaloids to form tobaccospecific N-nitrosamines (Nestor et al., 2003). High nitrate content increases the generation of nitrogen oxides (NOx) that, in turn, enhance the formation of tobacco-specific Nnitrosamines. In fact, the concentration of nitrogen oxides in tobacco smoke is predominantly given by the nitrate content, although a secondary fraction is formed from amino acids and proteins during smoking (Hoffmann and Hoffmann, 1997; Norman et al., 1983). Investigations carried out on a vast collection of cigarette brands, ranging from low to very high contents of both nitrate and tobacco-specific N-nitrosamines, concluded that nitrate concentration is linearly related to tobacco-specific N-nitrosamine content (Fischer et al., 1989; Hoffmann and Hecht, 1985; Hoffmann et al., 1997). Thus, a 
possible avenue for reducing nitrosamine levels in cigarette smoke is to reduce nitrate content in tobacco leaves (Hoffmann and Hecht, 1985).

However, an additional aspect merits consideration. Tobacco is a non-essential good, and its primary scope is to meet consumer satisfaction. The quality assessment for flue-cured tobacco in objective terms is currently based on the concentrations of leaf total alkaloids, reducing sugars, total nitrogen and their balance (Akehurst, 1981; Flower, 1999; Hawks and Collins, 1983). Therefore, any fertilization strategy intended to control nitrate levels should take into account possible detrimental effects on the relevant components.

The objectives of the present study were: (i) to evaluate the effect of nitrogen fertilization on yield, nitrate content and relevant chemical traits of flue-cured tobacco; and (ii) to assess the relationship between total nitrogen and nitrate content in tobacco leaves.

\section{MATERIALS AND METHODS}

\subsection{Site characterization and agronomic details}

A field experiment was conducted from 1997 to 1999 at the Experimental Farm of CRA, located in Bovolone (Verona), Northeast Italy (Lat. $45^{\circ} 16^{\prime} \mathrm{N}$, Long. $11^{\circ} 07^{\prime} \mathrm{E}$ ). The soil of the site was classified (Costantini et al., 2002) as coarseloamy, mixed, mesic, superactive Fluventic Haplustept (Soil Survey Staff, 1999). The location is representative of a vast area of flue-cured tobacco cultivation in Northeast Italy. Five levels of nitrogen fertilization were applied each year to fluecured tobacco (cultivar K 326). In the year 1997 the treatments were named N0, N15, N30, N45 and N60, in $\mathrm{kg} \mathrm{N} \mathrm{ha}^{-1}$. After evaluation of the 1997 results, in both 1998 and 1999 the nitrogen rates were slightly increased, so that treatments were named N0, N20, N40, N60 and N80, in $\mathrm{kg} \mathrm{N}^{-1}$. The nitrogen fertilizer was applied as calcium nitrate, in one localized application, two weeks after the transplanting of the crop. No phosphorus fertilizer was applied due to the abundance in the soil. The potassium was applied before transplanting at the uniform rate of $250 \mathrm{~kg} \mathrm{ha}^{-1}$ as potassium sulfate. For each year, a preceding crop of barley was harvested in July, and the soil remained fallow until tobacco transplantation. The crop was transplanted in mid-May; precisely, 15 May 1997, 13 May 1998 and 14 May 1999, by using a transplanting machine. A weed chemical control (Pendimethalin+Metobromuron+Metalachlor) was applied in May before transplanting. Topping was performed in the second half of July at the full flowering stage, followed by three applications of chemicals for sucker control (two treatments with fatty alcohol, one with maleic hydrazide). Chemical treatments to control aphids and blue mold (Imidacloprid or Acephate, and Metalaxyl) were applied before transplanting and in the field. Sprinkler irrigation, with volumes of $20 \mathrm{~mm}$, was applied during the growing season. This modest amount was imposed by the low infiltration capability of the soil. Total irrigation amounts were $220 \mathrm{~mm}$ in $1997,250 \mathrm{~mm}$ in 1998 and $158 \mathrm{~mm}$ in 1999.
Following the usual practice of the region, leaves were harvested, when ripe, in four primings, starting from the end of July until the end of October. The experimental design was a randomized block with two replications for a total of 10 plots. The dimension of an individual plot was $200 \mathrm{~m}^{2}$, the distance between the rows was $1 \mathrm{~m}$ and between plants within rows $0.45 \mathrm{~m}$, corresponding to 444 plants per plot (22 222 plants per ha). The experiment was specifically designed for collecting frequent destructive plant samples throughout the growing season. Therefore, priority was given to big plots at the expense of number of replications.

\subsection{Crop measurements}

Crop measurements were performed on two sampling scales: (i) a larger area, corresponding to one plant row in the central area of each plot, including 50 individuals, equivalent to $22.5 \mathrm{~m}^{2}$, was collected, on the mentioned four crop harvest dates per year, aiming to measure cumulated yield and nitrate, total nitrogen, reducing sugars and total alkaloids concentration in cured leaves; (ii) a smaller sample of two plants per plot, corresponding to $0.9 \mathrm{~m}^{2}$, was collected every week, starting in early June, with the scope of measuring the time courses of nitrate and total nitrogen content of leaves. In each individual plot a two-row buffer zone was excluded from sampling.

On the higher sampling scale, for each harvest the fresh leaves from the selected crop row were gathered and flue-cured on curing cells based on the system DELTA-T, in which humidity, temperature and air flux are constantly regulated in order to enhance the quality of the tobacco. Samples of the cured product were oven-dried at $65^{\circ} \mathrm{C}$ for $48 \mathrm{~h}$ to determine dry weight, and subsequently, sub-samples were collected for laboratory analysis: nitrate, total nitrogen, total alkaloids, and reducing sugars contents. On the lower sampling scale, the leaves of the two collected plants were detached and ovendried at $65{ }^{\circ} \mathrm{C}$ for $48 \mathrm{~h}$. Subsequently, sub-samples were selected for laboratory analysis to determine nitrate and total nitrogen contents over time. It is important to state that the smallsampling area was treated with the same agronomic management as the rest of the plot, including the four subsequent harvests.

\subsection{Chemical analysis}

Nitrate, total nitrogen, total alkaloids and reducing sugars contents were determined by colorimetric methods with a continuous flow automatic chemical analyzer (Technicon AutoAnalyzer, Technicon Industrial System, Tarrytown, NY 10591). Total nitrogen was determined as ammonia, after Kjeldhal digestion of tobacco powder, by the Berthelot reaction; ammonia reacts with sodium salicylate in the presence of hypochlorite to form a blue indophenol. Nitrate, free ammonia, total alkaloids and total reducing sugars were extracted in a $5 \%$ acetic acid solution. Nitrate was analyzed after reduction to nitrite by hydrazine sulfate and $\mathrm{Cu}^{2+}$ followed by formation of a red azo compound via diazonium salt. Free ammonia was determined using the same method for total nitrogen, 
without mineralization. Total alkaloids were determined after a reaction with on-line-generated cyanogen chloride and sulfanilic acid to form a yellow compound (Lidzey and Savage, 1986, modified by Contillo). Reducing sugars were analyzed through the formation of a yellow complex after a reaction with p-hydroxybenzoic acid hydrazide (Tonini et al., 1981).

\subsection{Statistical analysis}

Data of the year 1997 were analyzed separately, because of the specific treatments applied in the first year. Combined analyses were performed for the years 1998 and 1999, since common $\mathrm{N}$ rates were applied and no interactions between treatments and years arose. A combined analysis of variance and appropriate $\mathrm{F}$ tests were performed using the restricted maximum likelihood (REML) estimation method in the Proc Mixed procedure of SAS (Littell et al., 1996). The auto-correlation of subsequent harvests, applied to the same plants sampled in the large area with the intent of measuring dry matter yield, nitrate, total nitrogen, reducing sugars and total alkaloids concentrations of cured leaves, was taken into account using the REPEATED statement. The REPEATED statement was also used to consider the time and space auto-correlation of the smaller samples of two plants collected weekly with the intent of measuring the time course of total nitrogen and nitrate content of leaves. Denominator degrees of freedom were calculated using the Kenward-Roger approximation method to determine appropriate degrees of freedom. Mean separation comparison was performed by computing least-squares means through the LSMEANS SAS statement. Effects were considered significant at $P<0.05$.

With the intent of evaluating whether, and how, the total nitrogen is correlated to nitrate content the linear regression was calculated, using the PROC REG procedure of the SAS system (SAS, 1989). As a first step we calculated the linear regression over a large data set, including all the weekly sampling of the leaves, managed in individual plots during the growing seasons of the three years of the experiment $(n=1058)$.

Aiming to evaluate characteristics of the commercial product, the linear regression between nitrogen and nitrate content was also evaluated for the harvested and flue-cured leaves $(n=119)$. It is important to reiterate here that each experimental plot was harvested four times per year, and the commercial product was flue-cured.

\section{RESULTS AND DISCUSSION}

\subsection{Climatic conditions}

An overview of the prevailing climatic conditions throughout the growing seasons of the years 1997, 1998 and 1999 is reported in Figures 1 and 2, where daily average air temperature and cumulated precipitation are shown, respectively. The most important climatic difference among years was the amount and distribution of rainfall, which might have determined differentiated conditions of soil water content, nitrogen mineralization and nitrate leaching. Overall, the three

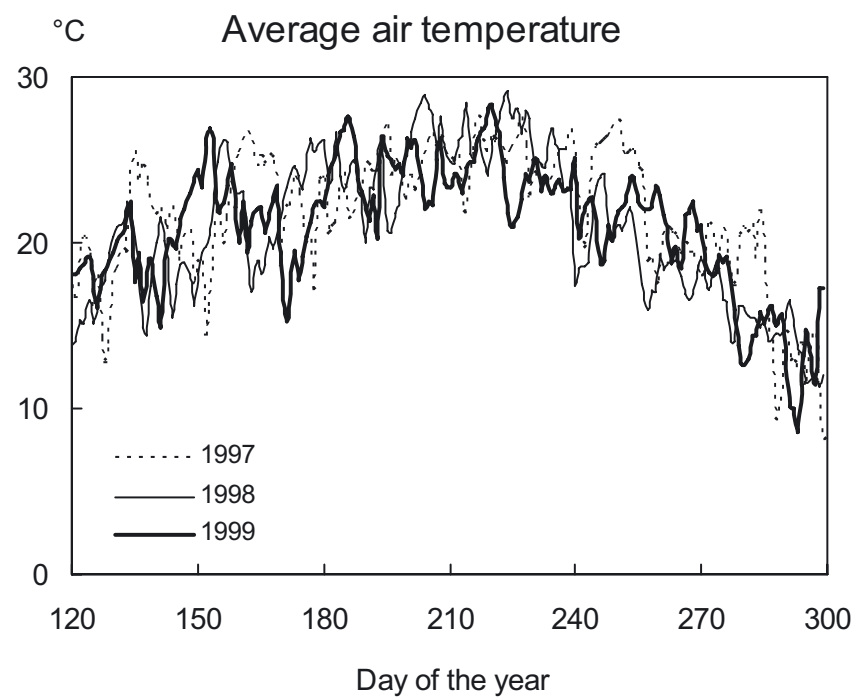

Figure 1. Time course of daily average air temperature for the three years of the experiment.

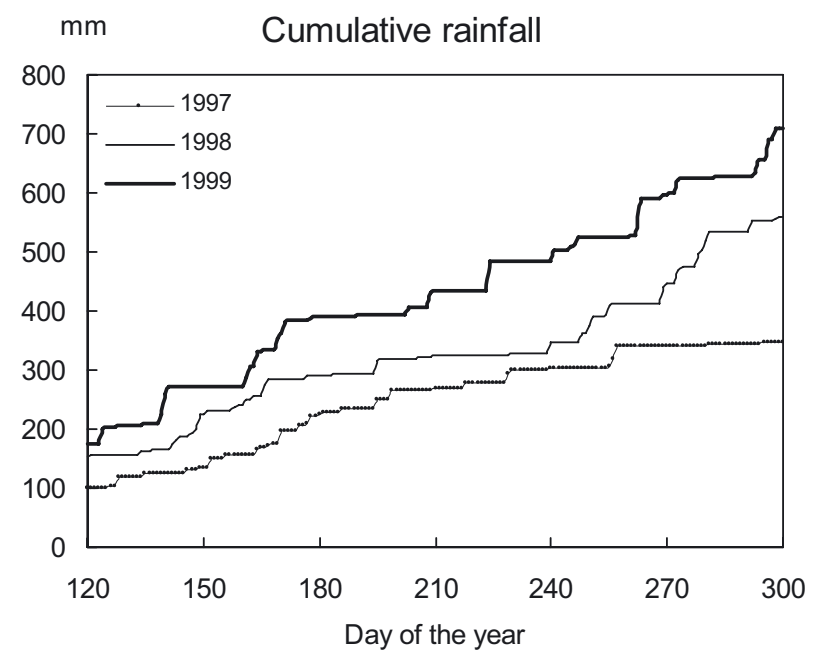

Figure 2. Daily values of cumulative precipitation for the three years of the experiment.

subsequent years of the experiment were representative of well-articulated growing seasons. In particular, the climatic conditions during spring 1997 were favorable for a massive aphid attack, which occurred in the whole region during the early phase of tobacco growth. Despite the chemical treatment against aphids normally applied, such an unusual aphid attack resulted in a widespread diffusion of tobacco viruses, affecting the crop for thousands of hectares in the region (European Commission, 2000; Forcato, 1997).

\subsection{Productivity and nitrate concentration}

The annual dry matter yield, nitrate, total alkaloids, reducing sugars and total $\mathrm{N}$ concentrations in cured leaves for individual treatments and the 3 years of the field experiment are 
Table I. Analysis of variance and mean values of yield, nitrate concentration, total alkaloids, reducing sugars, and total nitrogen in tobacco cured leaves. Separate analyses were carried out on 1997 data, due to the different amount of N supplied to the crops with respect to 1998 and 1999.

\begin{tabular}{|c|c|c|c|c|c|c|c|}
\hline Year & Effects & $\mathrm{N}$ rates & $\begin{array}{l}\text { Yield DM } \\
\left(\mathrm{Mg} \mathrm{ha}^{-1}\right)\end{array}$ & $\begin{array}{c}\text { NO3-N } \\
\left(\mathrm{g} 100 \mathrm{~g}^{-1}\right)\end{array}$ & $\begin{array}{c}\text { Total } \\
\text { alkaloids } \\
\left(\mathrm{g} 100 \mathrm{~g}^{-1}\right)\end{array}$ & $\begin{array}{c}\text { Reducing } \\
\text { sugars } \\
\left(\mathrm{g} 100 \mathrm{~g}^{-1}\right)\end{array}$ & $\begin{array}{c}\text { Total N } \\
\left(\mathrm{g} 100 \mathrm{~g}^{-1}\right)\end{array}$ \\
\hline \multicolumn{8}{|c|}{ Analysis of variance } \\
\hline 1997 & $\mathrm{~N}$ rate & & NS & NS & NS & NS & NS \\
\hline \multirow[t]{3}{*}{ 1998-99 } & $\mathrm{N}$ rate & & NS & $* * *$ & NS & $* *$ & NS \\
\hline & Year & & * & $* * *$ & NS & $* * *$ & NS \\
\hline & Year $\mathrm{x} N$ rate & & NS & NS & NS & NS & NS \\
\hline \multicolumn{8}{|c|}{ Comparisons among $\mathrm{N}$ rates } \\
\hline \multirow[t]{6}{*}{1997} & & No & $1.95 \mathrm{ab}$ & $0.4 \mathrm{a}$ & $3.0 \mathrm{a}$ & $6.8 \mathrm{a}$ & $4.2 \mathrm{a}$ \\
\hline & & N15 & $2.46 \mathrm{a}$ & $0.8 \mathrm{ab}$ & $3.4 \mathrm{a}$ & $7.0 \mathrm{a}$ & $4.6 \mathrm{a}$ \\
\hline & & N30 & $2.17 \mathrm{ab}$ & $0.7 \mathrm{ab}$ & $3.4 \mathrm{a}$ & $6.2 \mathrm{a}$ & $4.7 \mathrm{a}$ \\
\hline & & N45 & $1.31 \mathrm{~b}$ & $0.8 \mathrm{ab}$ & $3.0 \mathrm{a}$ & $4.9 \mathrm{a}$ & $4.4 \mathrm{a}$ \\
\hline & & N60 & $2.00 \mathrm{ab}$ & $1.1 \mathrm{~b}$ & $3.3 \mathrm{a}$ & $6.8 \mathrm{a}$ & $4.8 \mathrm{a}$ \\
\hline & & Means & 1.98 & 0.8 & 3.2 & 6.3 & 4.5 \\
\hline \multirow[t]{6}{*}{ 1998-99 } & & No & $3.75 \mathrm{a}$ & $0.3 \mathrm{a}$ & $2.4 \mathrm{a}$ & $10.9 \mathrm{a}$ & $2.3 \mathrm{a}$ \\
\hline & & $\mathrm{N} 20$ & $3.95 \mathrm{a}$ & $0.4 \mathrm{a}$ & $2.4 \mathrm{a}$ & $10.3 \mathrm{ab}$ & $2.3 \mathrm{a}$ \\
\hline & & N40 & $4.08 \mathrm{a}$ & $0.7 \mathrm{~b}$ & $2.6 \mathrm{a}$ & $8.5 \mathrm{bc}$ & $2.6 \mathrm{a}$ \\
\hline & & N60 & $3.98 \mathrm{a}$ & $1.0 \mathrm{bc}$ & $2.5 \mathrm{a}$ & $7.5 \mathrm{~cd}$ & $2.7 \mathrm{a}$ \\
\hline & & N80 & $3.85 \mathrm{a}$ & $1.2 \mathrm{c}$ & $2.6 \mathrm{a}$ & $6.6 \mathrm{~d}$ & $3.0 \mathrm{a}$ \\
\hline & & Means & 3.92 & 0.7 & 2.5 & 8.8 & 2.6 \\
\hline 1998 & & Means & $4.10 \mathrm{a}$ & $0.3 \mathrm{a}$ & $2.8 \mathrm{a}$ & $4.8 \mathrm{a}$ & $2.9 \mathrm{a}$ \\
\hline 1999 & & Means & $3.74 \mathrm{~b}$ & $1.1 \mathrm{~b}$ & $2.2 \mathrm{a}$ & $12.7 \mathrm{~b}$ & $2.2 \mathrm{a}$ \\
\hline
\end{tabular}

$\mathrm{NS}, * * *$ and $* * *$ refers to not significant at the 0.05 , and significant at the $0.05,0.01$ and 0.001 probability levels, respectively. Mean comparisons: means followed by the same letter are not significantly different at the 0.05 probability level. DM: Dry Matter.

reported in Table I. These data represent the cumulative, integrated values of four subsequent harvests performed throughout each individual growing season. Overall, both productivity and nitrate concentration were strongly influenced by the growing seasons. The year 1998 was characterized by the highest productivity, $+107 \%$ compared with 1997 and $+10 \%$ compared with 1999, respectively. The highest productivity of the year 1998 was associated with the lowest nitrate concentration. Compared with 1998, the average nitrate content was $+166 \%$ in 1997 and $+266 \%$ in 1999 .

Under our experimental conditions, the rates of nitrogen supplied had no significant effect on crop yield. Conversely, the effect of fertilization treatments in increasing nitrate content was quite evident. The rate N60 significantly increased nitrate content compared with N0 in 1997, while in both 1998 and 1999 the rate N40 significantly increased nitrate content compared with NO.

\subsection{Alkaloids content}

No significant effect on total alkaloids was found in the present experiment. However, the year 1997 was characterized by the highest average value of total alkaloids, $+14 \%$ compared with 1998 and $+45 \%$ compared with 1999, respectively. The highest content of alkaloids observed in 1997 is in good agreement with Latorre et al. (1984), who indicated that nicotine content in tobacco is increased by virus infections. However, the concentrations of alkaloids observed are within the

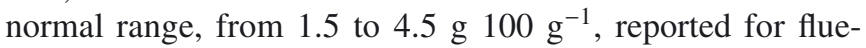
cured tobacco by Fisher (1999).

Our data indicate that alkaloids content is not significantly influenced by nitrogen fertilization. Our findings are in accordance with Chamberlain and Chortyk (1992) who observed, in an experiment with nitrogen rate applications ranging from 0 to $300 \mathrm{~kg} \mathrm{~N} \mathrm{ha}^{-1}$, little influence of nitrogen fertilization on alkaloids content. In contrast, Elliot and Court (1978), who applied fertilization rates ranging from 0 to $60 \mathrm{~kg} \mathrm{~N} \mathrm{ha}^{-1}$, observed an increment in total alkaloids leaf content of $+36 \%$ for the higher rate compared with the control.

From the standpoint of tobacco smokers the alkaloids play an extremely important role in tobacco quality because they provide a physiological stimulus that makes the use of tobacco products pleasurable to the smoker (Bush, 2000). Normally, nicotine accounts for 93-95\% of total alkaloids (Tso, 1990).

\subsection{Reducing sugars content}

Both years and nitrogen rates determined significant effects on reducing sugars concentration.

The highest average concentration of reducing sugars was observed in 1999, $+165 \%$ compared with 1998 and $+102 \%$ 
compared with 1999. In the years 1998 and 1999 nitrogen rates from N40 to N80 determined an undesired reduction of reducing sugars concentration. Hence, the effects of raising nitrate content were coupled with a reduction of reducing sugars in 1998 and 1999. We reiterate that the content of reducing sugars is considered an important quality trait for flue-cured tobacco, because of its influence on the characteristic sweet aroma of tobacco smoke. In fact, in blends with other tobacco types, the flue-cured component is used to enhance this characteristic (Peedin, 1999).

\subsection{Total nitrogen content.}

According to Akehurst (1981) and Hawks and Collins (1983), the flavor and pleasing qualities of the taste of smoke are directly correlated with the content of nitrogen. The higher the total nitrogen, the stronger and more pungent the taste will be. Conversely, if the content of nitrogenous constituents is too small the smoker regards the smoke as being flat and lacking pleasing qualities and flavor.

No significant effect on total nitrogen content was found in this experiment. However, higher values of total nitrogen were observed in the year 1997, +55\% compared with 1998 and $+104 \%$ compared with 1999 . The rate of nitrogen fertilization had little if any effect on total nitrogen concentrations. As previously stated, the detetrimental effects were to increase the nitrate concentration while decreasing reducing sugars content.

\subsection{Time course of nitrate concentration in tobacco leaves during the growing season}

Additional understanding of tobacco response to nitrogen fertilization can be gained from the time course of nitrate content of tobacco leaves during the growing season. These data were collected weekly on the smaller sampling area of each experimental plot for the three years of the experiment and provided an extensive data set. In Table II the analysis of variance, the mean values for each individual treatment, the intercept and the slope of the regression lines calculated between time, expressed in weeks after transplant, and the nitrate concentration of individual treatments are reported. These data confirm that nitrogen supply had a pronounced effect on nitrate content: in 1997 the treatments N15 and N30 were already different from N0, and the treatments N45 and N60 were different from both N15 and N30; in 1998-1999 the treatments N40, $\mathrm{N} 60$ and $\mathrm{N} 80$ were different from N0, and N60 and N80 were also different from N20. Overall, statistical differences among individual treatments are more evident in this data set, with respect to the results shown in Table 1, and this was likely due to the higher number of observations.

The slopes of the regression lines are negative for all treatments, and this indicates that nitrate content always decreased over time (Fig. 3). However, the interaction $\mathrm{N}$ rate $\mathrm{x}$ week was not significant, and this implies that individual regression has similar slopes. Hence, differences among treatments are attributable to differences in intercept, i.e. nitrate content at the outset of the growing season induced by rate of fertilization.
Table II. Analysis of variance and mean values of nitrate concentration in tobacco dried leaves collected during the growing seasons. Separate analyses were carried out on 1997 data, due to the different amount of N supplied to the crops with respect to 1998 and 1999.

\begin{tabular}{|c|c|c|c|c|c|}
\hline Year & Effects & $\mathrm{N}$ rates & \multicolumn{3}{|c|}{$\mathrm{NO}_{3}-\mathrm{N}\left({\left.\mathrm{g} 100 \mathrm{~g}^{-1}\right)}^{2}\right.$} \\
\hline \multicolumn{6}{|c|}{ Analysis of variance } \\
\hline \multirow[t]{2}{*}{1997} & $\mathrm{~N}$ rate & & $* * *$ & & \\
\hline & $\mathrm{N}$ rate $\mathrm{x}$ week & & NS & & \\
\hline \multirow[t]{4}{*}{ 1998-99 } & $\mathrm{N}$ rate & & $* * *$ & & \\
\hline & $\mathrm{N}$ rate $\mathrm{x}$ week & & NS & & \\
\hline & Year & & NS & & \\
\hline & Year $\mathrm{x} N$ rate & & NS & & \\
\hline \multicolumn{6}{|c|}{ Comparisons among $\mathrm{N}$ rates } \\
\hline & & & mean & intercept & slope \\
\hline \multirow{6}{*}{1997} & & No & $0.8 \mathrm{a}$ & $1.10 * * *$ & $-0.04 *$ \\
\hline & & N15 & $1.1 \mathrm{~b}$ & $1.44 * * *$ & $-0.04 * *$ \\
\hline & & N30 & $1.0 \mathrm{~b}$ & $1.46 * * *$ & $-0.05 * *$ \\
\hline & & N45 & $1.3 \mathrm{c}$ & $1.90 * * *$ & $-0.07 * * *$ \\
\hline & & N60 & $1.3 \mathrm{c}$ & $1.91 * * *$ & $-0.07 * * *$ \\
\hline & & Mean & 1.1 & & \\
\hline \multirow[t]{5}{*}{ 1998-99 } & & No & $0.4 \mathrm{a}$ & $0.77 * * *$ & $-0.04^{\mathrm{NS}}$ \\
\hline & & $\mathrm{N} 20$ & $0.7 \mathrm{ab}$ & $1.12 * * *$ & $-0.05 * *$ \\
\hline & & N40 & $0.9 \mathrm{bc}$ & $1.26 * * *$ & $-0.04 *$ \\
\hline & & N60 & $1.1 \mathrm{c}$ & $1.42 * * *$ & $-0.04 *$ \\
\hline & & N80 & $1.2 \mathrm{c}$ & $1.47 * * *$ & $-0.03 *$ \\
\hline 1998 & & Mean & $0.5 \mathrm{a}$ & & \\
\hline 1999 & & Mean & $1.2 \mathrm{a}$ & & \\
\hline
\end{tabular}

$\mathrm{NS}, *, * *$ and $* * *$ refers to not significant at the 0.05 , and significant at the 0.01 and 0.001 probability levels, respectively. Means followed by a common letter are not significantly different at the 0.05 probability level.

This is consistent with the general knowledge that solar irradiance reduces nitrate concentration (Cardenas-Navarro et al., 1999). Our data indicate that nitrogen fertilization, applied two weeks after transplant, sharply increased the nitrate concentration of the leaves at the outset of the growing season. Because the nitrate content decreased in the subsequent part of the growing season for all treatments, the initial effect was never cancelled, and at the end of the crop cycle the differences in nitrate concentration induced by fertilization still remained.

\subsection{Nitrate and total nitrogen content relationship}

In Figure 4 the linear regression between total nitrogen and nitrate content in the dried leaves is shown. These data refer to samples collected weekly during the growing season. Overall, the linear regression explains only $30 \%$ of the observed variability. In fact, high nitrate content is often associated with low total nitrogen content and vice versa. Hence, total nitrogen can be considered as a poor predictor of the nitrate content of tobacco leaves throughout the growing season. However, one might notice that leaves of flue-cured tobacco are harvested, normally on 4 subsequent dates, during the final part of the growing season, when nitrate content normally declines. 

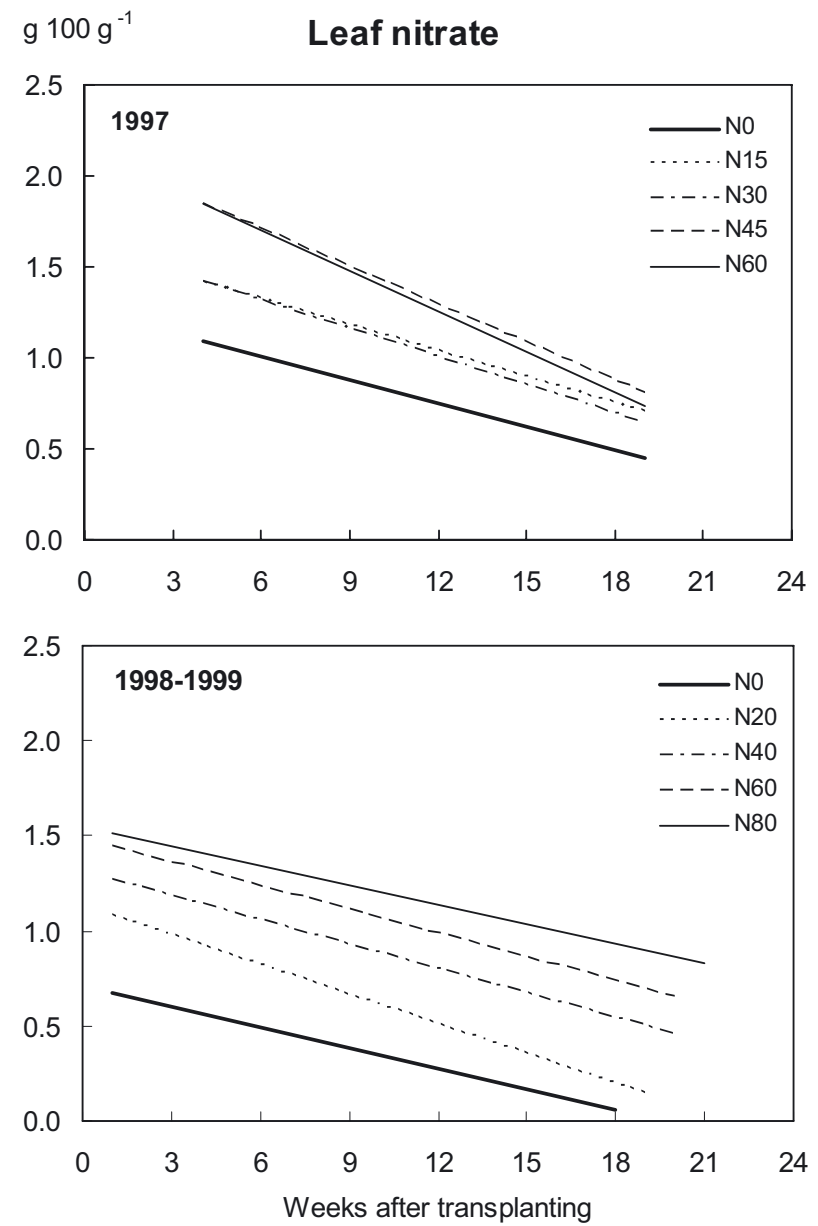

Figure 3. Lines of best fit for the relationship between time and nitrate content in the leaves for individual fertilization treatments applied in the year 1997 and in the subsequent years 1998 and 1999.

Moreover, the product used for smoking is flue-cured, and this treatment could further influence the nitrate and nitrogen content. Consequently, it is appropriate to consider the relationship between total nitrogen and nitrate concentration in the harvested and cured product. In Figure 5 the linear regression between total nitrogen and nitrate content in the harvested and flue-cured product is shown. We found no significant relationship between total nitrogen and nitrate concentration.

\section{CONCLUSION}

Under our environmental conditions fertilization rates within $40 \mathrm{~kg} \mathrm{~N} \mathrm{ha}^{-1}$ fulfilled the crop's need for productivity with no adverse impact on product quality. This fertilization level should not be exceeded because higher rates of nitrogen supply resulted in undesired increment in nitrate concentration and reduced sugar content in the cured product, without any gain in productivity. The level of $\mathrm{N}$ supply that should not be exceeded might be different under diverse climatic and soil fertility conditions. Therefore, it is crucial to take the content of

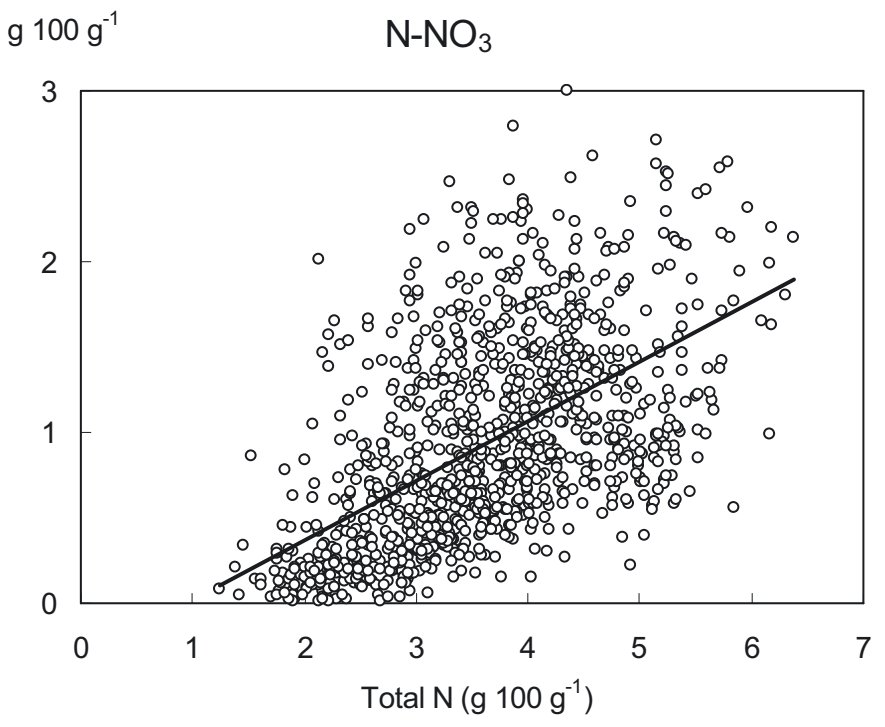

Figure 4. Relationship between leaf nitrate and total nitrogen content in tobacco leaves. Data refers to dried leaves sampled throughout the growing season. $\mathrm{N}^{-\mathrm{NO}_{3}}=-0.27 * * *+0.33^{* * *}$ Total $\mathrm{N} ; \mathrm{R}^{2}=0.30$, $\mathrm{n}=1055$.

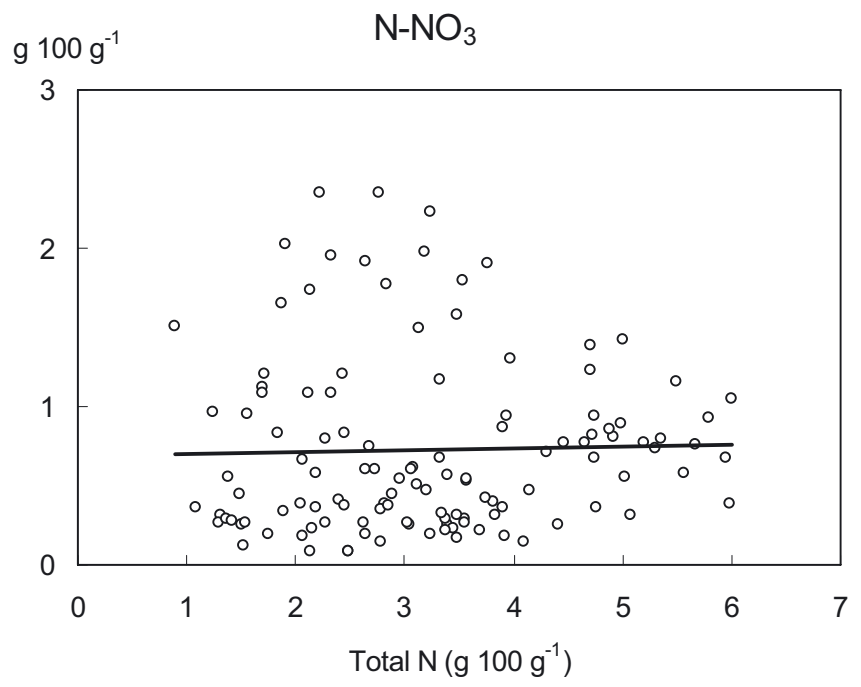

Figure 5. Relationship between leaf nitrate and total nitrogen content in tobacco leaves. Data refers to the harvested and flue-cured product. $\mathrm{N}-\mathrm{NO}_{3}=0.68 * * *+0.014^{\mathrm{NS}}$ Total $\mathrm{N} ; \mathrm{R}^{2}=0.001, \mathrm{n}=119$.

harmful nitrate under control. Our data provide evidence that total nitrogen is not correlated with the harmful nitrate content in the flue-cured product. The routine analysis of commercial flue-cured tobacco currently determines total alkaloids, reducing sugars, total nitrogen, pesticides and chemicals for sucker control residues, but not nitrate content. Because total nitrogen is not a reliable estimator of nitrate, we suggest that nitrate content should be included in the analysis for assessing tobacco quality. 
Acknowledgements: This experiment was financed jointly by the Italian Ministry of Agriculture and Forestry Policies and the Commission of the European Communities, Tobacco Information and Research Fund, project 96/T/67: "Diminution des taux de composés indésirables dans le tabac par l'utilisation d'outils d'aide à la gestion de la fertilisation azotée". It does not necessarily reflect the views of the Commission and in no way anticipates its future policy in this area.

\section{REFERENCES}

Akehurst B.C. (1981) Tobacco, 2nd ed., Tropical Agriculture Ser., Longman, London and New York.

Anjana U.S., Iqbal M. (2006) Nitrate accumulation in plants, factors affecting the process, and human health implications. A review, Agron. Sustain. Dev. 27, 43-57.

Blumenthal J., Baltensperger D.D., Cassman K.G., Mason S.C., Pavlista A.D. (2001) Importance and effect of nitrogen on crop quality and health, in: Follett R.F, Hatfield J.L. (Eds.), Nitrogen in the environment: sources, problems and management, Elsevier Science, New York, USA, pp. 45-63.

Bush L. (2000) Tobacco alkaloids. Past, present and future, CORESTA Information Bull., 2000 CORESTA Congress, Lisbon, Portugal, pp. 29-31.

Cardenas-Navarro R., Adamowicz S., Robin P. (1999) Nitrate accumulation in plants: a role for water, J. Exp. Bot. 50, 613-624.

Chamberlain W.J., Chortyk O.T. (1992) Effects of curing and fertilization on nitrosamine formation in Bright and Burley tobacco, Beitr. Tabakforsch. 15, 87-92.

Costantini E.A.C., Castelli F., Raimondi S., Lorenzoni P. (2002) Assessing soil moisture regimes with traditional and new methods, Soil Sci. Soc. Am. J. 66, 1889-1896.

Elliot J.M., Court W.A. (1978) The effects of applied nitrogen on certain properties of flue-cured tobacco and smoke characteristics of cigarettes, Tob. Sci. 22, 54-58.

European Commission (2000) Aiuto di Stato n. N 15/2000 - Italia (Veneto). Deliberazione n. 3896 del 9 novembre 1999: aiuti a favore dei tabacchicoltori, http://ec.europa.eu/community_law/state_ aids/agriculture-2000/n015-00.pdf.

Fisher P. (1999) Cigarette manufacture. Tobacco blending, in: Davis D.L., Nielsen M.T. (Eds.), Tobacco: production, chemistry and technology, Blackwell Publishing Ltd., Oxford, UK, pp. 346-352.

Fischer S., Spiegelhalder B., Preussmann R. (1989) Preformed tobaccospecific nitrosamines in tobacco - role of nitrate and influence of tobacco type, Carcinogenesis 10, 1511-1517.

Flower K.C. (1999) Agronomy and physiology. Field practices, in: Davis D.L., Nielsen M.T. (Eds.), Tobacco: production, chemistry and technology, Blackwell Publishing Ltd., Oxford, UK, pp. 76-103.
Forcato E. (1997) Per il tabacco un'annata disastrosa, L'Inf. Agrario 44 Suppl. Triveneto, 6-7.

Hawks S.N. Jr., Collins W.K. (1983) Principles of flue-cured tobacco production, 1st edition, N.C. State University, Raleigh, NC, USA.

Hoffmann D., Djordjevic M.V., Hoffmann I. (1997) The changing cigarette, Preventive Medicine 26, 427-434.

Hoffmann D., Hecht S.S. (1985) Nicotine-derived N-Nitrosamines and tobacco-related cancer: current status and future directions, Cancer Res. 45, 935-944.

Hoffmann D., Hoffmann I. (1997) The changing cigarette, 1950-1955, J. Toxicol. Environ. Health 50, 307-364.

Latorre B.A., Flores V., Marholz G. (1984) Effect of potato virus Y on growth, yield, and chemical composition of flue-cured tobacco in Chile, Plant Dis. 68, 884-886.

Lidzey R.G., Savage G.P. (1986) An automated procedure for the determination of total alkaloids in cigarette smoke using on-line cyanogen chloride generation from low hazard starting material, Beitr. Tabakforsch. 13, 151-155.

Littell R.C., Milliken G.A., Stroup W.W., Wolfinger R.D. (1996) SAS System for Mixed Models, SAS Institute Inc., Cary, NC, USA.

Nestor T.B., Gentry J.S., Peele D.M., Riddick M.G., Conner B.T., Edwards M.E. (2003) Role of oxides of nitrogen in tobacco-specific nitrosamine formation in flue-cured tobacco, Beitr. Tabakforsch. $20,467-475$.

Norman V., Ihrig A.M., Larson T.M., Moss B.L. (1983) The effect of some nitrogenous blend components on $\mathrm{NO} / \mathrm{NOx}$ and $\mathrm{HCN}$ levels in mainstream and sidestream smoke, Beitr. Tabakforsch. 12, 5562.

Peedin G.F. (1999) Production practices. Flue-cured tobacco, in: Davis D.L., Nielsen M.T. (Eds.), Tobacco: production, chemistry, and technology, Blackwell Publishing Ltd., Oxford, UK, pp. 104-142.

SAS (1989) SAS/STAT User's Guide, 4th ed., Vol. 1, SAS Institute, Cary, NC.

Soil Survey Staff (1999) Soil taxonomy: a basic system of soil classification for making and interpreting soil surveys, 2nd ed., USDANRCS Agric. Handb. 436, US Gov. Print. Office, Washington, DC, USA.

Tonini A., Comella S., Mellone G. (1981) Automated determination of total alkaloids, reducing sugars, total nitrogen, and ammonia in tobacco using an AutoAnalyzer, Ann. Ist. Sperim. per il Tab., Scafati, SA, Italy, 77-88.

Tso T.C. (1990) Production, physiology and biochemistry of tobacco plant, Ideals Inc., Beltsville, MD, USA.

Wolfe A.H., Patz J.A. (2002) Reactive nitrogen and human health: acute and long-term implications, Ambio 31, 120-125. 